2020, Volume 10, International Conference Globalization, Innovation and Development. Trends and Prospects (G.I.D.T.P.), pages: 335-343 |

https://doi.org/10.18662/lumproc/gidtp2018/37

\section{Several Causes and Sustainable Solutions of School Dropout in Romania}

\section{Laura Monica GORGHIU, Roxana Constanta ENACHE2, Ana-Maria Aurelia PETRESCU3*, Gabriel GORGHIU ${ }^{4}$}

${ }^{1}$ Valahia University Targoviste, Targoviste, Romania, lgorghiu@gmail.com

2 Technical University of Civil Engineering, Bucharest, Romania, rocatare@yahoo.com

\section{${ }^{3}$ Valahia University Targoviste, Targoviste, Romania, anapetrescu2007@yahoo.com}

Corresponding author

${ }^{4}$ Valahia University Targoviste, Targoviste, Romania, ggorghiu@gmail.com
Abstract: The school dropout phenomenon involves an extremely complex causality and - at the same time - represents a difficult and sensible problem faced by the contemporary society, not only in Romania, but also in the whole European area. Through this paper, we aim to identify the views of a sample of primary and secondary teachers concerning the causes of the school dropout in the Romanian school and the effectiveness of social and/or educational policies implemented so far. We also propose - following the investigative research - to identify and underline several sustainable solutions, in order to be applied in the context of the Romanian society and educational system, regarding the prevention and mitigation of this phenomenon. At macro level, it is important to increase the access to education, mostly in the case of disadvantaged students. At micro level, monitoring the students with big potential of school dropout and adopting of measures which limit this phenomenon seem to be crucial. In this format, just the primary and secondary teachers were questioned, but the research illustrated in this paper was carried out in order to justify and prepare a Grant dedicated to limit the university students drop-out, in the frame of the ROSE programme.

Keywords: school dropout; educational policies; social policies; general compulsory education; ROSE Project.

How to cite: Gorghiu, L.M., Enache, R.C., Petrescu, A.M.A., \& Gorghiu, G. (2020). Several Causes and Sustainable Solutions of School Dropout in Romania. In I. Panagoreț \& G. Gorghiu (vol. ed.), Lumen Proceedings: Vol. 10. International Conference Globalization, Innovation and Development. Trends and Prospects (G.I.D.T.P.) (pp. 335-343). Iasi, Romania: LUMEN Publishing House.

https://doi.org/10.18662/lumproc/gidtp2018/37 


\section{Introduction}

School dropout represents a serious and complex issue of the contemporary society and implicitly of the actual education/learning systems. In general, the phenomenon of school dropout is defined as "an extreme form of manifestation of the school failure which consists in interrupting the studies as early as the compulsory general education stage" [1].

The school dropout may be analyzed from three different perspectives: pedagogical, social and even economic. The pedagogical perspective highlights certain aspects relating to early school dropout, school inadaptation, failure to meet the learning objectives set for a specific level of education. The social perspective refers to the dysfunctions entailed by the school dropout in terms of the correlation between the compulsory education and the post-compulsory education, respectively the labor market, whereas the economic perspective tackles this phenomenon as an indicator of the inefficacy of the learning/education system.

Cristina Neamțu [5:199] considers that "school dropout represents the conduct of definitive evasion consisting in discontinuing school attendance, leaving the education system, irrespective of the level reached, prior to acquiring a complete qualification or professional certification or prior to the end of the study cycle in progress."

From our point of view, this phenomenon is manifested in the students' conscious withdrawal from the formal education system, prior to acquiring an elementary, basic training. Regarding to the types of school dropout in line with the criterion of the generating causes, we consider that they may have a very powerful social impact.

In the Romanian education system, school dropout has been an alarming phenomenon over the past few years as it covers a large series of causes while the methods to prevent and diminish them take effect with difficulty.

\section{Few Statistical Data Concerning School Dropout}

According to the Education and Training Monitor 2016 - Romania (volume II) [3], there are more and more young persons who dropped out prior to completion of their studies, whereas the early dropout rate in Europe has diminished.

Therefore, the rate for Romania went up from $15.3 \%$ in 2008, to $17.8 \%$ in 2012 , then going up to $19.1 \%$ in 2015 , mentioning as national rate 
set for 2020 to a percentage of $11.3 \%$ - difficult to be met in such context [4].

The dropout rate for 2016 in Romania reached $18.5 \%$, with a slightly higher rate only for Malta (19.6\%) and Spain (19\%) [1]. Furthermore, according to the data provided by the National Institute of Statistics, the school dropout in primary and secondary education represents one of the most serious issues of the Romanian education system at both national and European levels, where Romania is on the third place $(12.1 \%)$, after Republic of Moldova (17,9\%) and Macedonia (13.1\%) [6].

The Eurostat Report for 2017 [4], dedicated to Early leavers from education and training, demonstrates that the school dropout rate in Romania records a slightly descending trend, with a value of $18.1 \%$. Moreover, the school dropout rate for the whole number of the EU Members States is stated to have reached an average value of $10.6 \%$ in 2017 , compared to $10.7 \%$ in 2016 [4].

\section{Casuistry of the School Dropout Phenomenon}

As mentioned in national and international statistics (some of them are recalled above), the reasons - for a considerable number of students - to leave a form of schooling, especially in the general compulsory education sector, are equally linked to the educational system dysfunctions and to the socio-economic problems of their family and/or community. In many cases, the problems raise mainly from the student: learning difficulties, physiological, psychological or mixed deficiencies.

Therefore, schools in the disadvantaged areas are isolated, poor and deprived of opportunities for graduates to succeed socially and professionally. Lacking motivation, many students in the secondary classes drop out as early as the first years of study and end up helping around the house or working as day-laborer. The poverty of the communities in the disadvantaged areas reduces the parents' possibilities to provide their children with the resources needed for education. In many cases, the poverty often triggers the exploitation of children by their parents for working purposes. The tendency to consider that the families in the disadvantaged areas do not value the importance of education positively is superficial. The indifference to school is explained by the pressures of economic status, by the parents' personal disappointments and the lack or the poor representation of some cultural values within the local community.

Additionally, by reference to the students' culture of origin, the researches in the education field showed that the students' socio-cultural 
environment of origin is one of the most important variables involved in the phenomenon of school dropout. Knowing the family's attitude in relation to school and identifying the sources of some potential tensions or blockages manifested in relation to continuation of studies by students, constitute an important factor in preventing the school dropout.

The family climate is equally decisive in terms of causes of school dropout. Therefore, a disorganized family life, as a consequence of the divorce, the conflicted and immoral family climate, which is either excessively permissive or authoritarian, the divergent educational methods, the cold, indifferent attitude of the parents, are all reasons which determine students to abandon their studies.

There are social and economic factors (political, economic, social and moral crises, inconsistency of the welfare system, confusing norms or values or their absence, negative entourage etc.) that contribute to get students confused, estranging them from the educational environment and finally, having an important role to the emergence of the school dropout. There are also educational factors (poor motivations and interests in relation to school/education, educative mistakes made by teachers in terms of their attitude towards students with learning difficulties or students who come from disadvantaged social environments, professional incompetence of the teaching staff and school leaders etc.) which lead to insubordination attitudes to school norms and regulations, phenomena such as truancy, absenteeism, school failure, grade repetition and finally school dropout.

A Report published in the framework of the project "Efficient solutions to prevent school dropout: costs and mechanisms", designed by UNICEF and Educatia 2000+ Centre, identifies three main categories of causes which contribute to school dropout [7:22-24]:

I. Causes related to the student and his/ her family:

- Material difficulties; siblings;

- Educational models provided by the parents and/or elder

- Family environments characterized by divorce, alcoholism, violence etc.;

- Activities at the edge of the law: deviant behavior, prostitution, gang affiliation or integration in begging networks;

- Labor market, often as laborer, without an employment contract;

- Low trust in the education and learning system, in particular;

- Human migration.

II. Causes related to the community: 
- Norms concerning early marriage and sometimes the birth of a child (especially in the rural area and in the rromani communities);

- Lack of security in the community area, which affects the communication between the school and the student's family;

- Norms concerning the non-continuation of education after the $8^{\text {th }}$ grade.

III. Causes related to the school environment:

- Constant and frequent repetitions of grades;

- Insufficient integration in the classroom;

- Quality of the relations with teachers and colleagues.

Having this complex situation, the solutions for lowering the school dropout rates must consider all the trigger factors and must treat this phenomenon in a holistic way, by correlating the educational policies and practices with those specific to the social, economic, community and health public ones.

\section{Methodology}

\subsection{Objectives}

The research study mainly aims at two objectives, namely:

a. Identification of the perceptions of the teachers involved in the focus-group discussions with regards to the casuistry of the school dropout and the amplitude of this phenomenon;

b. Identification of some potential solutions to prevent and reduce the school dropout at national level and in each school institution.

\subsection{Participants}

This investigation brought together a number of 60 teachers from the primary and secondary education, from Argeş, Dâmbovița and Prahova Counties, including also the municipality of Bucharest. 15 teachers from each mentioned region participated to the focus groups, ensuring the representativeness related to the following criteria: gender, age, rural/urban area, schooling level.

\subsection{Procedure}

Therefore, four focus-groups were designed, each consisting of 15 participants. The discussions held with each group were structured in line 
with the principles of the focus-group survey and lasted 45 to 50 minutes (on average). The following key questions addressed to all participants were:

- To what extent do you consider that the phenomenon of school dropout exists in your school?

- What do you think about the causes of this phenomenon?

- To what extent are the school, as institution, and the teachers, as educational agents, responsible for the emergence of this phenomenon?

- What solutions do you think should be approached in terms of educational policies nationwide and European-wide, in order to prevent and reduce the school dropout rate?

- What solutions do you think should be approached in terms of current educational and social practices?

The responses were recorded and partially written down on paper, by each moderator.

\section{Results and Discussion}

Regarding the extent to which the phenomenon of school dropout exists in their school institutions, the teachers appreciated it as a reduced one, with slight increases in the schools from the rural area, but also in the schools attended mainly by rromani students.

With reference to the casuistry of the school dropout phenomenon, the respondents consider that the causes are mainly of social nature, in close relation to the material status of the family, the parents' educational/cultural level, dysfunctions of the family life (divorces, violence, failure to take parental responsibility etc.). Another cause is the migration of the parents who left Romania and tried to seek jobs in other countries.

Another challenge had as central question the extent to which the school (as institution) and the teachers (as educational agents) are responsible for the phenomenon of the school abandonment. Most respondents stated that they personally do not feel responsible for this phenomenon. Nevertheless, approximately $20 \%$ of them admitted the fact that the school (as institution) and the teachers, implicitly, may not be exonerated of the responsibility related to the phenomenon of school dropout. Therefore, the teachers asserted that there are persons/committees appointed to monitor the school dropout in each school institution. Formally, there are action plans designed to prevent and diminish this phenomenon. Nonetheless, in practical terms, those actions are either unoperational or ignored. In this context, the participants raised a series of issues concerning: the multitude of roles and responsibilities of a teacher 
(especially when the teacher is a headteacher/class leader), the difficulties related to the communication with parents, the insufficient support which some authorities provide to schools and disadvantaged families etc. In the interviewees' opinion, all those elements are solid arguments intended to support the idea according to which the school dropout can be charged to teachers or school institutions only in a small extent. With reference to the solutions to prevent and diminish the school dropout rate, which should be approached in terms of educational policies at national and European level, the participants mentioned:

- Increasing the education access rate, especially for students from disadvantaged socio-economic environments;

- Raising awareness among parents with regards to how important is for the children to continue their studies;

- Combating social, cultural, economic, racial, ethnic, religious segregation and discrimination within schools and communities;

- Promoting more flexible educational routes (for instance, vocational and dual education), intended to counterpose the informative and the formative aspects.

With respect to the solutions meant to prevent and diminish the school dropout rate which should be approached in relation to current educational and social practices, the following ideas were highlighted:

- Additional state or local budget funds allocated for schools which are forced to combat a high dropout rate;

- Appropriate infrastructure which should provide transportation and possibly food to students who live further from school, or to families who cannot afford such expenses;

- Improving the teacher-student-family relation, by involving the parents in educational partnership activities;

- Permanently monitoring of the students who are exposed to the dropout risk;

- Conducting some remedial/compensatory educative activities for the students with learning difficulties;

- Getting the school involved in projects/programmes, aiming to reduce the school dropout rates;

- Lifelong training of teaching staff, focusing on action strategies regarding prevention and reduction of the school dropout phenomenon etc. 


\section{Conclusions}

The phenomenon of school dropout is extremely complex, due to its various causes and also the multitude of factors which should be considered in order to eradicate it.

The discussions held with teachers participating in the focus group indicated that most of them are aware of how serious this phenomenon present in the Romanian schools is - however, only some teachers manage to identify operational solutions related to the system and, to a greater extent, to the process, solutions which are necessary to appropriately approach this phenomenon towards preventing and reducing it.

Consequently, we consider that it is more than necessary to efficiently correlate the macro-level to the micro-level solutions, the educational policies and the practices instituted within schools, on the one hand, and the teachers' conduct, in particular, on the other hand.

Beyond all and beyond any social and/or educational policy, the teacher's pedagogical attitude [2], the affective relation established between teacher and students, the professional devotion shown by the teacher when assuming his/her noble mission, the enthusiasm, the spiritual force, all those can turn the balance in the favour of continuing the studies of his/her students and implicitly, can contribute to the reducing of the school dropout rate.

\section{Acknowledgements}

The research carried out in this paper had the support of the 3-years project entitled $<<$ The "Pro Academica" Learning Center - Services and Logistic Support for Students> (ROSE Grant Agreement no. 81/SGU/CILI/18.12.2017), having the objective to limit the students dropout rate in the first year of study, especially for those ones who are in risk situations, by developing specific activities in a dedicated learning center. We thank to all the primary and secondary teachers involved in the illustrated research. The authors contributed equally to this paper.

\section{References}

[1]. Balaban C. România, locul trei în UE la abandonul şcolar; 2017. Available from: https://www.agerpres.ro/social/2017/09/08/romania-locul-trei-in-uela-abandonul-scolar-10-44-19 [Accessed 6th February 2020].

[2]. Cristea S. Dicționar enciclopedic de pedagogie, vol. 1. Bucuresti: Didactica Publishing House; 2015. 
[3]. European Union. Education and Training Monitor 2016. Romania, vol. II; 2016. Available from: $\underline{\text { http://europski- }}$ fondovi.eu/sites/default/files/dokumenti/monitor2016-countryreports en.pdf [Accessed 6th February 2020].

[4]. Eurostat. Report on Early leavers from education and training; 2017. Available from: https://ec.europa.eu/eurostat/statisticsexplained/index.php/Early \%20leavers from \%20education and $\% 20$ traini ng [Accessed 6th February 2020].

[5]. Neamțu C. Devianța şcolară. Ghid de interventie în cazul problemelor de comportament al elevilor. Iaşi: Polirom; 2003.

[6]. Dinica S, Iurisniti C, Presada F, Chiru A, Stefan S. Atelier de lucru: Reducerea abandonului școlar. Atelier din cadrul evenimentului "Educația, încotro?" 2018. Available from: https://www.usr.ro/proiect/reducerea-abadonuluiscolar-atelier-din-cadrul-evenimentului-educatia-incotro/ [Accessed 6th February 2020].

[7]. Voicu B. (coord.). Renunțarea timpurie la educație. Posibile căi de prevenire. Bucureşti: Vanemonde; 2010. 